The University of Maine

\title{
DigitalCommons@UMaine
}

Earth Science Faculty Scholarship

Earth Sciences

3-1993

\section{Methanesulfonic Acid in Coastal Antarctic Snow Related to Sea-ice Extent}

\author{
K.A. Welch \\ Paul Andrew Mayewski \\ University of Maine, paul.mayewski@maine.edu \\ S. I. Whitlow
}

Follow this and additional works at: https://digitalcommons.library.umaine.edu/ers_facpub

Part of the Climate Commons, Glaciology Commons, Hydrology Commons, and the Oceanography Commons

\section{Repository Citation}

Welch, K. A.; Mayewski, Paul Andrew; and Whitlow, S. I., "Methanesulfonic Acid in Coastal Antarctic Snow Related to Sea-ice Extent" (1993). Earth Science Faculty Scholarship. 189.

https://digitalcommons.library.umaine.edu/ers_facpub/189

This Article is brought to you for free and open access by DigitalCommons@UMaine. It has been accepted for inclusion in Earth Science Faculty Scholarship by an authorized administrator of DigitalCommons@UMaine. For more information, please contact um.library.technical.services@maine.edu. 


\title{
METHANESULFONIC ACD IN COASTAL ANTARCTIC SNOW RELATED TO SEA-ICE EXTENT
}

\author{
K. A. Welch, P. A. Mayewski, and S. I. Whitlow
}

Glacier Research Group, Institute for the Study of Earth, Oceans and Space, University of New Hampshire

Abstract. Proxy records of biogenic sulfur gas obtained from ice cores suggest that variability in marine biogenic sulfur emissions may reflect changes in climate [Saigne and Legrand, 1987; Legrand et al., 1988, Legrand et al., 1991; Anderson and Charlson, 1991]. Increased sea-ice extent has previously been proposed as one cause of relatively high methanesulfonic acid (MSA) in glacial-age ice core samples [Gibson et al., 1990]. We have analyzed MSA, one of the oxidation products of the biogenic sulfur gas dimethylsulfide [Hatakeyama et al., 1985], from snowpit samples recovered from a coastal site in Southern Victoria Land, Antarctica. Time series of MSA correlate significantly with the longest continuous record available of Southern Ocean sea-ice extent (two decades) [Jacka, 1990].

\section{Introduction}

Methanesulfonic acid (MSA, $\mathrm{CH}_{3} \mathrm{SO}_{3} \mathrm{H}$ ) and sulfur dioxide $\left(\mathrm{SO}_{2}\right)$ (which is converted in the atmosphere to nonsea-salt sulfate (nss-SO ${ }_{4}=$ )) are the two major oxidation products of dimethylsulfide (DMS) [Hatakeyama et al., 1985], a sulfur gas that is associated with some types of marine phytoplankton [Gibson et al., 1990; Vairavamurthy et al., 1985]. Unlike nss-SO $\mathrm{S}_{4}=\mathrm{MSA}$ is thought to be exclusively derived from biogenic sulfur gases. It has been suggested that variations in MSA concentration in ice cores reflect biological activity [Legrand et al., 1991, Legrand and Feniet-Saigne, 1991; Saigne and Legrand, 1987].

Previously, sea-ice extent has been linked to marine productivity via growth of phytoplankton in ice [Clarke and Ackley, 1984], under ice [Bunt and Wood, 1963; Bunt, 1963], and/or in the low density melt layers at receding ice edges [Ackley et al., 1979; Olson, 1980; Deacon, 1982; Jennings et al., 1984; Smith and Nelson, 1985; Bodungen et al., 1986; Nelson et al., 1987]. DMS producers [Bodungen et al., 1986] and high DMS concentration in seawater [Berresheim, 1987] have been found in regions where packice is drifting. The production of DMS by marine phytoplankton has also been related to salinity [Vairavamurthy et al., 1985]. The precursor for DMS is DMSP, an osmoregulator. High salinity in brine pockets in sea-ice may be related to an increase in DMSP production in algae [Gibson et al., 1990]. Increased sea-ice extent has been proposed as one cause of relatively high MSA in glacial-age ice core samples [Gibson et al., 1990]. In the present work we examine the relationship between the available Southern Ocean sea-ice extent record and the MSA record from Newall Glacier, Southern Victoria Land, Antarctica.

Copyright 1993 by the American Geophysical Union.

Paper number 93GL00499

0094-8534/93/93GL-00499\$03.00

\section{Methods}

Samples were recovered from a snowpit in the accumulation zone of the Newall Glacier $\left(162^{\circ} 30^{\prime} \mathrm{E}, 77^{\circ} 35^{\prime} \mathrm{S}\right)$ in the Ross Sea region of Antarctica (Figure 1). The sampling location was at approximately $1600 \mathrm{~m}$ elevation. The snowpit was sampled using an interval of approximately $2.25 \mathrm{~cm}$ which resulted in an average of 6 samples per year. The samples were analyzed for MSA by ion chromatography using a Dionex model 4000 instrument with a gradient pump and an Omnipak 500 column. In addition, $\mathrm{Na}^{+}, \mathrm{Cl}$, and total beta activity analyses were performed using methods described elsewhere [Whitlow et al,, 1992]. The snowpit was dated using peaks in total beta activity and seasonal peaks in $\mathrm{Na}^{+}$and $\mathrm{Cl}^{-}$[Dibb et al., 1990; Warburton and Young, 1981] (uncertainty is estimated to be $+/-1$ year) (Figure 2).

The sea-ice data were obtained from the U. S. Navy/NOAA maps of the northern limit of sea-ice extent. We obtained records of sea-ice extent compiled by Jacka [1990] which included the distance from the South Pole to the ice edge for every $10^{\circ}$ of longitude for one map each month from 1973 through 1990 . The sea-ice area for each month was determined by calculating the area for each $10^{\circ}$ wedge, summing them and then subtracting the continent area. The monthly sea-ice area in the Ross Sea region was determined by using the distance to the ice edge from $160^{\circ} \mathrm{E}$ to $130^{\circ} \mathrm{W}$ longitude. These were the boundaries for the Ross Sea region used by Zwally et al. [1983].

\section{Results and Discussion}

In order to test the hypothesized association between MSA and sea-ice [Gibson et al., 1990], the record of MSA from the Newall Glacier snowpit was compared to the continuous record of sea-ice from the Southern Ocean and the

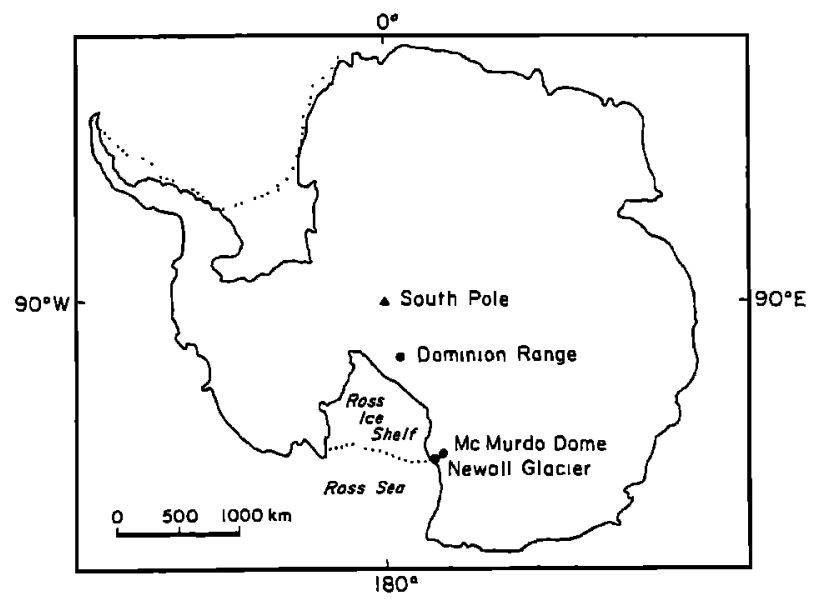

Fig. 1. Map of Antarctica showing site locations. 

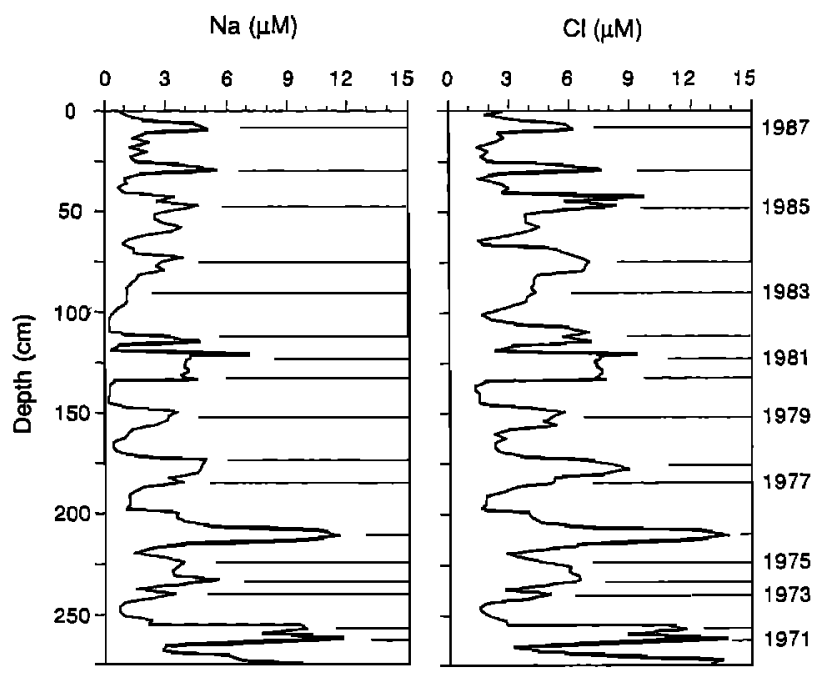

Fig. 2. Sodium and chloride profiles from the Newall snowpit used for dating.

Ross Sea region [Jacka, 1990] (Figure 3). The MSA depth profile has been converted to a time series based on the dating of the snowpit. The two sea-ice records are similar since much of the variability in the Southern Ocean sea-ice record is due to changes in the Ross Sea region [Zwally et al., 1983].

While monthly sea-ice data are available, the low accumulation rate at Newall $\left(4.2 \mathrm{~g} \mathrm{~cm}^{-2} \mathrm{yr}^{-1}\right)$ precludes dividing the data by months, hence annual averages were calculated for MSA and sea-ice in order to provide a direct statistical comparison. Correlation coefficients for the relationship between mean annual MSA concentration and mean annual sea-ice area for the Southern Ocean (SO) and Ross Sea (RS) are 0.802 and 0.768 , respectively (significant at $99 \%$ ). The annual flux of MSA, determined as $\mu \mathrm{eq} \mathrm{cm}^{-2}$ $\mathrm{yr}^{-1}$, is also significantly correlated to sea-ice area $(\mathrm{R}=0.749$ and 0.709 for SO and RS, significant at $99 \%$ ).

Because conditions influencing DMS production are highly variable during the year in the region of the Southern Ocean it would be preferable to examine the relationship between seasonal sea-ice extent and seasonal MSA, however since our MSA data cannot readily be converted into monthly or seasonal averages it was not possibly to make this type of comparison.

The annual sea-ice and MSA records were checked for persistence using a one year lag test of autocorrelation. When time series with persistence are correlated, for example, when there are multi-year trends in the data, the results can be suspect. Significant autocorrelation was found $(R=0.630$, $0.614,0.586$ for the SO, RS, and MSA records respectively, significant at $99 \%$ ), however, there was negligible autocorrelation for the difference from one year to the next for each of the variables $(R=-0.190,-0.166,0.027)$. The year to year differences of MSA and sea-ice were significantly correlated at the $95 \%$ confidence level $(R=0.522,0.655$ for SO, RS) indicating that the correlation between MSA and seaice is not due to the fact that each record is autocorrelated.

The relationship between MSA and sea-ice was investigated for other antarctic MSA records (Figure 1) including South Pole [Legrand and Feniet-Saigne, 1991], McMurdo Dome (unpublished data), and Beardmore Glacier in the Dominion Range [Whung, 1991; Mayewski et al., 1990]. Notably, no significant relationships were found. Of the four sites surveyed, Newall is the closest to the coast and appears to be the most sensitive to changes in sea-ice extent. Antarctic MSA data suggest that coastal areas are primarily affected by local sources of biogenic sulfur while precipitation on the antarctic plateau reflects lower latitude DMS sources [Legrand et al., 1992]. While McMurdo Dome is located fairly close to the coast it is believed to represent deposition from a region affected primarily by inland air masses and would, therefore, not display as strong a relationship to sea-ice as a site fed primarily by coastal precipitation.

In addition to the suggested relationship of sea-ice extent to MSA there may also be a connection between sea-ice and El Nino-Southern Oscillation events (ENSO) due to the influence of sea-ice extent on southern hemisphere atmospheric circulation although this remains unclear [Carleton, 1989]. While a physical link between ENSO and MSA deposition in Antarctica has not yet been deternined [Legrand and Feniet-Saigne, 1991; Legrand et al., 1992], it is likely that the MSA records from Antarctica reflect a combination of ENSO, sea-ice extent, plus other factors and that the relative importance of these influences is related to geography and atmospheric circulation. For example, South Pole is more influenced by mid-latitude air masses travelling to the antarctic plateau [Saigne and Legrand, 1987; Legrand and Feniet-Saigne, 1991] while Newall Glacier should be more directly affected by coastal precipitation.

High MSA concentration in south polar snow has previously been related to ENSO events [Legrand and FenietSaigne, 1991, Quinn et al., 1987]. Both the South Pole and Beardmore Glacier MSA records are thought to be influenced by ENSO events, although for South Pole some sea-ice influence was also suspected [Legrand and Feniet-Saigne, 1991; Whung, 1991]. Although the record of MSA from Newall closely reflects sea-ice extent, some peaks in MSA concentration may correspond to ENSO events given the uncertainty in the dating. However, the MSA records from the Newall glacier and South Pole are different reflecting the difference in atmospheric circulation and source region for MSA at the two sites.

\section{Conclusion}

Since instrumental records from the Antarctic are fairly limited, MSA concentration in Newall firn can only be directly compared to an 18 year long record of sea-ice extent However, the relationship between sea-ice extent and Newall Glacier MSA is strong and there is significant documentation of processes that could promote such a relationship. The longer record of MSA obtained from an ice core at Newall Glacier may reflect the variability in sea-ice extent and provide a valuable record of sea-ice over the past several thousand years.

Acknowledgements. We thank B. Lopez, B. Lyons, M. Twickler, C. Wake, B. Koci and colleagues from PICO for their assistance in the field, M. J. Spencer for advise and help in the lab, J. Dibb for providing information that assisted in the dating of the snowpit and for comments, T. H. Jacka for 


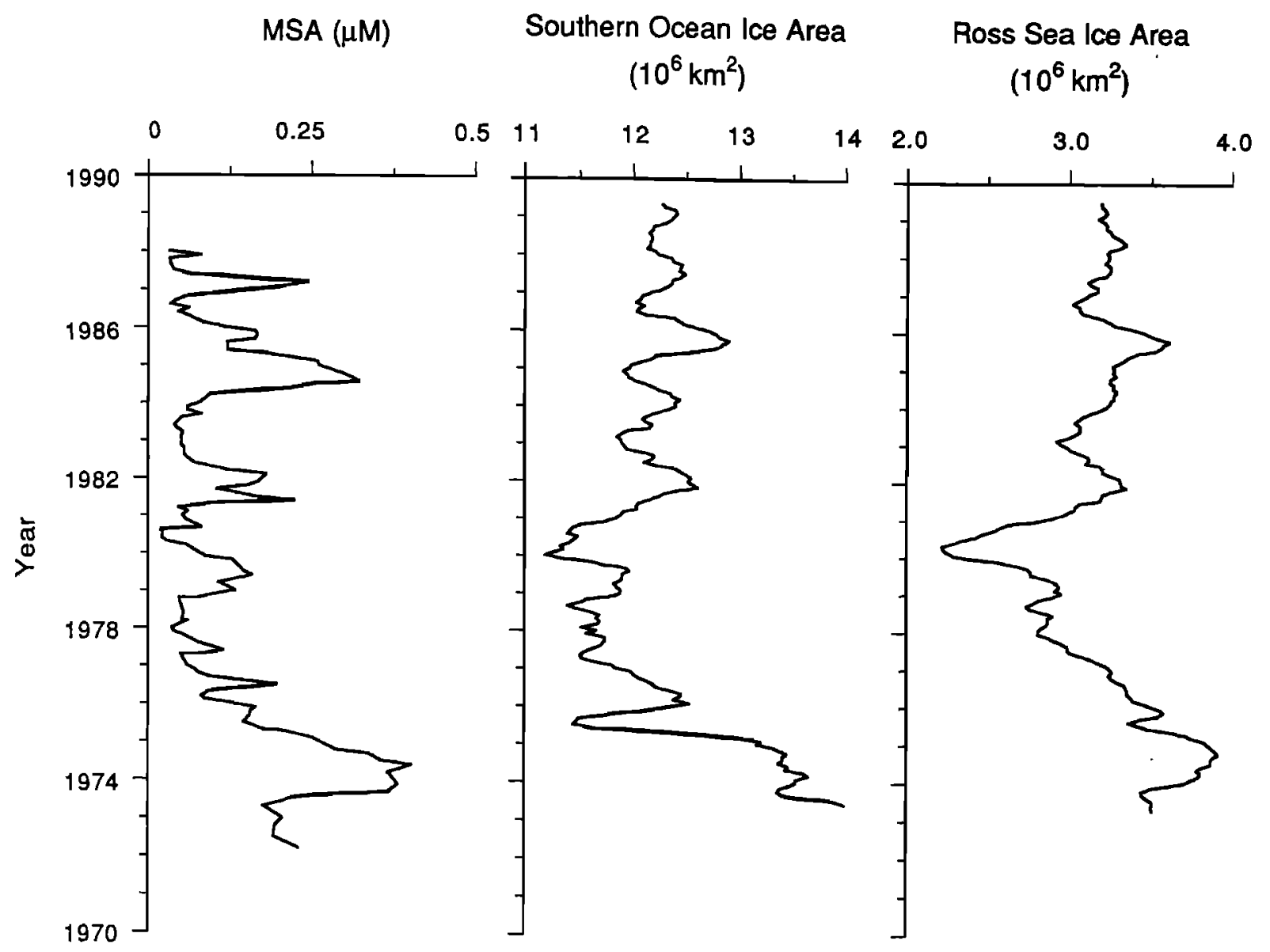

Fig. 3. MSA from the Newall Glacier snowpit and sea-ice area for the Southem Ocean and Ross Sea. Records of sea-ice from the Navy/NOAA maps of the northern limit of sea-ice extent for every $10^{\circ}$ of longitude from 1973 through 1990 [Jacka, 1990] were used to calculate the monthly sea-ice area for the Southern Ocean and the Ross Sea sector. The amplitude of the seasonal change in sea-ice area is much larger than the year to year variability so the sea-ice record was smoothed using a 12 month running mean in order to visually compare it to the record of MSA from the snowpit.

providing the sea-ice records, and P. Grootes for providing the McMurdo Dome snowpit samples. We also thank the reviewers of an earlier manuscript for their helpful comments. This research was supported by the NSF DPP grant 8613786.

\section{References}

Ackley, S. F., K. R. Buck, and S. Taguchi, Standing crop of algae in the sea ice of the Weddell Sea region, DeepSea Res., 26A, 269-281, 1979.

Anderson, T. L., and R. J. Charlson, Geophysiology of natural marine sulfate aerosols, Atmos. Environ., 25, 2445-2447, 1991.

Berresheim, H., Biogenic sulfur emissions from the subantarctic and antarctic oceans, J. Geophys. Res., 22 , 13245-13262, 1987.

Bodungen, B. v., V. S. Smetacek, M. M. Tilzer, and B. Zeitzschel, Primary productivity and sedimentation during the spring in the Antarctic Peninsula region, Deep-Sea Res., 33, 177-194, 1986.

Bunt, J. S., Diatoms of antarctic sea-ice as agents of primary production, Nature, 199, 1255-1257, 1963.
Bunt, J. S., and E. F. J. Wood, Microalgae and antarctic sea ice, Nature, 199, 1254-1255, 1963.

Carleton, A. M., Antarctic sea-ice relationships with indices of the atmospheric circulation of the Southerm Hemisphere, Climate Dynamics, 3, 207-220, 1989.

Clarke, D. B., and S. F. Ackley, Sea ice structure and biological activity in the antarctic marginal ice zone, $\mathrm{L}$ Geophys. Res., 89, 2087-2095, 1984.

Deacon, G. E. R., Physical and biological zonation in the Southern Ocean, Deep-Sea Res., 22, 1-15, 1982.

Gibson, J. A. E., R. C. Garrick, H. R. Burton, and A. R. McTaggart, Dimethylsulfide and the alga Phaeocystis pouchetii in antarctic coastal waters, Mar. Biol., 104, 339-346, 1990.

Hatakeyama, S., K. Izumi, and $\mathrm{H}$. Akimoto, Yield of $\mathrm{SO}_{2}$ and formation of aerosol in the photo-oxidation of DMS under atmospheric conditions, Atmos. Environ., 19, 135$141,1985$.

Jacka, T. H., Antarctic and Southern Ocean sea-ice and climate trends, Annals Glaciol., 14, 127-130, 1990.

Jennings, J. C., Jr., L. I. Gordon, and D. M. N'elson, Nutrient depletion indicates high primary productivity in the Weddell Sea, Nature, 309, 51-54, 1984. 
Legrand, M., and C. Feniet-Saigne, Methanesulfonic acid in South Polar snow layers: A record of strong El Nino?, Geophys. Res. Lett., 18, 187-190, 1991.

Legrand, M., C. Feniet-Saigne, E. S. Saltzman, and C. Germain, Spatial and temporal variations of methanesulfonic acid and non-sea-salt sulfate in antarctic ice, J. Atmos. Chem.; 14, 245-260, 1992.

Legrand, M., C. Feniet-Saigne, E. S. Saltzman, C. Germain, N. I: Barkov, and V. N. Petrov, Ice-core record of oceanic emisssions of dimethylsulphide during the last climate cycle, Nature, 350, 144-146, 1991.

Mayewski,P. A. et al., The Dominion Range ice-core, Queen Maud Mountains, Antarctica-General site and core characteristics with implications, J. Glaciol., 36, 11-16, 1.990.

Nelson, D. M., W. O. Smith, Jr., L. I. Gordon, and B. A. Huber, Spring distributions of density, nutrients, and phytoplankton biomass in the ice edge zone of the Weddell-Scotia Sea, J. Geophys. Res., 22, 7181-7190, 1987.

Olson, R. J., Nitrate arid ammónium uptake in Antarctic wäters, Limnol. Oceanogr., 25, 1064-1074, 1980.

Quinin W. H., V. T. Neal, and S. E. Antunez de Mayolo, El Nino occurrences over the past four and a half centuries, J. Geophys. Res., 92, 14449-14461, 1987.

Saigne, C., and M. Legrand, Measurements of methảnesulfonic acid in Antarctic ice, Nature, 330, 240$242,1987$.
Smith, W. O. and D. M. Nelson, Phytoplankton bloom produced by a receding ice edge in the Ross Sea: Spatial coherence with the density field, Science, 227, 163-166, 1985.

Vairavamurthy, A., M. O. Andreae, and R. L. Iverson, Biosynthesis of dimethylsulfide and dimethylpropiothetin by Hymenomonas carterae in relation to sulfur source and salinity variations, Limnol. Oceanogr., 30, 59-70, 1985.

Whitlow, S., P. A. Mayewski, and J. E. Dibb, A comparison of major chemical species seasonal concentration and accumulation at the South Pole and Summit, Greenland, Atmos. Envir., 26A, 2045-2054, 1992.

Whung, P.-Y., A study of methanesulfonic acid in ice cores, Ph. D. dissertation, University of Miami, Miami, June, 1991.

Zwally, H. J., C. L. Parkinson, and J. C. Comiso, Variability of antarctic sea ice and changes in carbon dioxide, Science, 220, 1005-1012, 1983.

P. A. Mayewski, K. A. Welch, and S. I. Whitlow Glacier Research Group, Institute for the Study of Earth, Oceans and Space, University of New Hampshire, Durham, New Hampshire 03824

(Received: Octobër 27, 1992;

Accepted: January 22, 1993) 